\title{
A Cultural-Historical Appraisal of Three Selected Sacred Spaces of the Eastern Free State: A Phenomenological Approach
}

\author{
Dalifa H.D. Ngobese \\ Mogomme A. Masoga
}

\section{Abstract}

The existence of cave sites in the eastern Free State poses a number of challenges to cave dwellers, cave pilgrims, heritage practitioners, and landowners and for the continued preservation, management and restoration of the caves. This study investigates the history and contemporary significance of Mantsopa, Mautse, and Motouleng caves. The caves have special religious significance for some African indigenous religious persuasions, indigenous knowledge systems and traditional healers, in relation to the veneration and reverence of ancestors. This is a qualitative descriptive study and was conducted to describe the locality, history and importance of the caves, with an interrelated theoretical and conceptual framework focused on concepts from African Religion, landscape, and social identity. It also includes a brief focus on contestations between cave dwellers and cave pilgrims on the one side and landowners of the lands on which the caves are situated. An interpretive phenomenological analysis of data in terms of available scholarship, was deployed. The purpose of the study was to identify and briefly analyse aspects of the significance of the caves for African religious and indigenous knowledge experiences and practices. A secondary purpose was to assess challenges concerning contestations about the caves between cave dwellers and pilgrims, and landowners, and to find out how these sites could be protected, both physically and legally, and also how existing protests and contestations by cave pilgrims may be dealt with constructively. It is recommended that access is negotiated with the landowners, and awareness regarding the religious and 
cultural practices and beliefs of the cave pilgrims are created to ensure the continuation and appreciation of African traditional religion and indigenous knowledge systems, in these sacred spaces.

Keywords: sacred space, caves, eastern Free State, African Religion, beliefs and practices, ancestors, social identity, healing rituals, sangoma, contestations, protest

\section{Introduction}

Coplan (2003) mentions that sacred sites, in particular caves, have not been accorded their rightful place in South African society, neither in concept nor practice. Based on the evidence accumulated by this study, we argue that sacred sites have always been part of the historical, cultural and spiritual landscape of various African indigenous communities. Historically, the sacred sites in question are rich in cultural and historical remnants of Later Iron Age and Anglo-Boer War origins. However, colonial ignorance and a deprivation legacy of African cultural and spiritual expressions have contributed as major obstacles to acknowledging the invaluable role the sites play.

We argue that the connection between the sacredness of the site and pilgrimages remains unexplored in relation to ritual practices, healing, initiation, religious rites and ceremonies. Cave dwellers have, through their rites of passage, paid tribute to certain belief systems, which this article will allude to throughout.

Coplan (2003) gives a descriptive survey of a number of current sacred sites in the eastern Free State, which are located in an area ranging from the north of Lesotho to the Caledon River border in the south. He points out that,

... each of these sites is a sacred ritual shrine to miracles made visible by the ancestors, located in a high shallow cave near the stream ... (2003:34).

The mere existence of sacred sites gives rise to an unique set of arguments in relation to historical incidents, activities and sacred spaces that are not concepttually and physically separated from each other, and contingently related. The meaning of sacred space always involves a subjective dimension, is symbolically constructed, and involves relationships between actors and places. 
Victor Turner frequently refers to the notion of a holy place, for sacred space. Turner's writings were heavily influenced by Eliade, who maintains that religious sites are sacred spaces that allow direct or mediated contact with the divine (1963:85). The article seeks to explore alternative views to the notion that accords sites embedded meaning. Tilley (1994:9), for example, suggests that the sacred space is, literally, nothingness, a space for simple surface action, and that it lacks depth. Such a view obviously denies the ontology of sacred sites, and deprives them from acquiring intrinsic and depth meaning for users of sacred space.

The article starts with a reassessment of the key factors underpinning the value Mantsopa, Mautse, and Motouleng caves have for various religious persuasions, the view that they are sacred and the way they are used for ancestor veneration by traditional healers in particular and Africans generally. This article also provides a historic-theoretical understanding of cave sites in the eastern Free State. By focusing on a number of important influences on African religion and belief systems, as codification of African indigenous religions, the discussion is based on narrations of personal experiences of the cave dwellers of their pilgrimages and how they perceive sacred spaces in relation to access contestation, ritual performance and pertinent nodes of identity construction in a vibrant and changing society.

\section{Background and Outline of the Problem}

One of the exceptional episodes in the non-racial, democratic South Africa after 1994, was the escalation of pilgrimages to various spiritual sites in the eastern Free State. A very strong belief in the supernatural powers of these holy places lead people to converge on the sites, to be trained as sangoma or to pray and sacrifice in honour of their ancestors.

Due to the disrupting effects these pilgrimages have on farms, landowners have been negatively inclined concerning pilgrims visiting the sacred sites. In one instance, a farmer has even threatened to blow up a cave. These threats were prompted by incidents of rustling and trespassing and an influx of pilgrims from the neighbouring country of Lesotho. An SABC documentary, Special Assignment, broadcast on 10 October 1998, validated the rumours that a farmer intended to blow up a certain cave that was considered sacred. 
Community belonging, experiences and people's identities relating to sacred spaces represent the discourse relevant to this study. We, therefore, narrate this discourse as defined by African belief systems, diviners' calling, spiritual expressions and symbols and ritual performances, in order to render a strong sense of communal identity and religious practices.

It is important to point out that sacred sites are referred to by cave dwellers as their homes, which provide the capacity and comprehension of the intellect, and the needs of the emotion and spirit. It is an interesting exercise to trace the experiences through which a sacred site, to a degree, generates a sense of being; and serves as the place where the person's and environment's identities overlap.

What the cave dwellers practice and perceive within the sacred sites remains a taboo to outsiders, and also to a repository of indigenous knowledge. Thus, this article involves not only the discovery of pre-existing patterns, but also the creation of relationships that do not exist in absolute terms. Among the most important phenomenological aspects of sacred sites are issues that relate to the theorising of African Religion, landscape, and social identity. The next section briefly describes the sacred cave sites, followed by an outline of some of the theoretical considerations and conceptual framework, focused on, and the methodology employed in the research.

\section{Sacred Caves of the Eastern Free State: Case Studies}

We will start by examining the historical background of the sacred sites of Mantsopa, Mautse and Motouleng. The whole area, across the sites, is rich in cultural and historical remnants, from the Iron Age and, more recently, the Anglo-Boer War. Geo-historical aspects related to these sites, directly affect the research analyses and data interpretation - both empirical and from published research - as these relate to and can be integrated into informed understandings of the cave dwellers and their views and experiences, in the contemporary period.

Below, we provide brief descriptions of each site, including geographical features, historical and religious aspects (cf. Coplan 2003:978). These brief descriptions provide a foundation for the data analysis and interpretation of the three selected sacred sites, which will follow, the descriptions below. 


\section{Nkgono Annah Mantsopa Cave Site}

The Nkgono Annah Mantsopa site of veneration and ritual practices, is situated within the premises of the St. Augustine Anglican church. The cave, known as 'The Cave Church', is situated at Modderpoort farm, $5 \mathrm{~km}$ north of Ladybrand. This property, which Bishop Edward Twills purchased in 1869, is situated within the so-called 'Conquered Territory', which was lost by the Basotho through conquests in the years 1843 to 1869 (Coplan 2003:979). The article does not probe this history here, and also not the operations of the Anglican church at Modderpoort, except to flag this fact of the relationship between The Cave Church, Nkgono Annah Mantsopa, and the Anglican Church.

Families who settled in Lesotho during the 1870s revered the spiritual gifts of Nkgono Annah Mantsopa, who was a traditional healer, prophetess, and Mosheoshoe's seer. Becker (1969:238) reports that King Moshoeshoe relied far more on the prophecies and philosophies of his seers and diviners, including Mantsopa, than on advice from missionaries. During his era, two of his seers/ diviners were Mantsopa Makhetha, a woman, and Katsi, a blind man. They were said to possess extraordinary powers of healing. Warriors who drank their special concoctions were believed to become invulnerable to the settlers' bullets (Becker 1969:238).

Amongst others, Becker (1969) reports that Mantsopa predicted the era of the Difaqane by prophesying that the black tribes would be wiped out by a fellow tribe. Documents in Morija Archives in Lesotho confirm that Mantsopa had told Moshoeshoe that the Basotho had to ready themselves, because an enemy would appear, but that it would also destroyed in a battle to be known as 'the battle of hail'. Thereafter, the people would be able to sow and harvest as before, without fear (Becker 1969:174). Mantsopa also predicted that the struggle would be short and sharp and so fierce that it would be remembered as Ntwa ya sefako (the battle of hail) (Becker 1969:175). Mantsopa became a famous prophetess with much influence amongst the Basotho. She also took on the role of coaxing rain through prayer.

With regard to her claims to also be a rainmaker, when Mantsopa failed to produce rain, as she had promised, at one point, she was divested of her riches by the eldest son of Moshoeshoe, King Letsie of Lesotho. She was also condemned by Moshoeshoe as a charlatan, and Letsie drove her over the Orange River into exile (Becker 1969:239). Having been exposed to Christianity, at this point, Mantsopa tried to merge African Religion with 
Christianity. By 1868, she was catechised by French missionaries at Thaba Bosiu, and two years later, in March 1870, she was baptised as a Christian, despite her indigenous beliefs and practices. She nevertheless worked as a faithful Christian with French Protestants, and later with the Anglicans in Modderpoort. Anna Nkgono Mantsopa died in 1906, at the age of about 111 years, and was buried in the Anglican church cemetery at Modderpoort.

\section{Mautse Cave Site}

The Mautse valley sacred cave lies on a farm situated between the towns of Fouriesburg and Rosendal in the Free State. The entire district around Badimong (place of ancestors) was known as Mautse, as it had been the stronghold of the powerful chief of the Batlokwa, Chief Segonyela, since the first half of the $19^{\text {th }}$ century.

According to legend, tales of the inhabitants of Mautse valley are traced back nearly 1000 years. Coplan (2003:979) regards the valley a conquered land, ${ }^{1}$ thereby referring to land that was previously occupied by Black communities before the White man came, and unoccupied by the colonist.

This article argues that the Black people of the valley and far beyond have been pursuing strategies of re-appropriation and reconnection with the land of their ancestors. African people believe that the land cannot be leased or sold. In resisting colonisation, Basotho people entered into a series of wars with the settlers in the 1860s (Davenport 1977:104). They lost these battles. As a result, the Basotho communities were forced to leave their villages, and their ripening crops, and accept newly introduced boundaries.

Since the time that they have been separated from the sacred cave site, traditional healers and representatives of independent African healing churches began not to not only conduct rituals and fertility and cult initiations at the site, but also to collect the powdered reeds from Nkokomohi, for rituals, as the place

${ }^{1}$ Coplan's (2003) notion of 'conquered land' developed because the land had been appropriated, seized, taken ('conquered') after the defeat of the African people and later 'transferred' to white authorities. Once the land had been transferred, the white authorities moved the local Africans away from the area and absorbed them into the colonial system, especially the colonial labour system. As such, they had to vacate the area, and in the process, became detached from their cultural roots, and lost their land and land ownership. 
is commonly known by pilgrims. At certain points in their history, the indigenous people have also lived in and at the caves, in addition to people sometimes taking refuge there overnight or in bad weather. As certain rituals of healing and training or divination could take weeks or months, cave dwellers also sometimes built rude mud, sandstone, and thatched houses in the cave, and in the vicinity of the cave. Needless to say, these practices also raised the chagrin of the white farmers in the area.

\section{Motouleng Cave Site}

The name of Motouleng cave, as it is known indigenously by cave pilgrims, is translated as 'the place where the drum beats'. The town closest to Motouleng cave is Clarens, which is situated between Rooiberge and Mount Horeb. Motouleng is surrounded by the Maluti and Drakensberg Mountains, is close to the historic site Surrender Hill, and situated by the R26 road between Clarens and Fouriesburg. After taking the gravel road from Surrender Hill, one travels close to $6 \mathrm{~km}$ through Braamhof farm to the signpost indicating Motouleng Heritage Site, where cave dwellers and pilgrims enter the site.

Historically, it is essential to trace the cave's existence as part of the history of Clarens, the closest town to Motouleng. As is the case for other sacred sites in the Free State, little literature has been published on the history of Clarens. Rev. Piet Grobler, former minister of the Dutch Reformed Church in Clarens, wrote a book called Clarens 1900 - 2000, which remains part of unpublished material on Clarens.

Motloung (2003:36) explains that there was a direct declaration of war between King Moshoeshoe, leader of the Basotho people, and the Voortrekkers, led by Paul Kruger, in 1865, in Lesotho and the Free State respectively, after five burghers were brutally assassinated by Basothos. Eventually, the Basotho were defeated at Nauwpoort and they fled to the mountain in Thaba Bosiu, Lesotho. Coplan (2003:978) confirms that the period between 1840 and 1870 was one of almost constant conflict between Basotho and Boers, with other Bantu, Griqua, and even San people doing their part to keep the pot boiling. Throughout this period, the caves and slopes along the Caledon River served as hideaways, ramparts, lairs and battlefield sites. Given this reality, Motloung (2003:35) points out that the aftermath of the $19^{\text {th }}$ century wars led to the construction and development of a town called Clarens in 1921, which is also known as the 'Jewel of the Free State'. 


\section{Theoretical and Conceptual Framework}

Against the brief background of the geo-history of the sacred caves above, the research for this article is interpreted within theories and conceptual frameworks related to African Religion, landscape, sacred space or sacred sites, and social identity. These are outlined below, and are used to elucidate the indigenous religious practices of the users of the three selected sacred sites of the eastern Free State.

\section{African Religion}

Concepts and categories of the theorising of African Religion may be used, as a theoretical framework for understanding the activities, patterns and symbolic operational intricacies found at the sacred sites. A brief account of the general ideas of African religion in relation to the significance of sacred space is outlined in this section.

Scholars consider African Religion to be the framework for an African epistemology that indicates how important geographical spaces are to this religion. The religion is also linked to sacred objects in different spaces, in particular, as rocks/ stones, trees, rivers, mountains, pools, springs, and caves. Lebel and Hubert (1995), Cox (1992) and Eliade (1959) agree that sacred spaces, the objects in these sacred spaces, and the rituals practices in such spaces, are attached to particular symbolisms and meanings of a particular culture or religion. In the culture, these spaces carry a whole range of meanings associated with cultic practices, human behaviour, and sets of beliefs connected to a non-empirical world.

Taylor (1963:35 - 40) suggests that African people are inclined to objectify attitudes and feelings, so that what happens inside a person spills out to touch not only other people, but even the environment. His argument is based on the religious principle of the African religion, which is permeated by an awareness of the spiritual and invisible dimensions of life, which fosters harmony and well-being.

We affirm the work by Setiloane (1986) on African traditional religion, who defines African worship through a holistic approach. According to Setiloane, the notion of 'worship' does not sufficiently capture the relationship of the African to the sacred. It involves much more, in so far as the relationship of the African to divinity, involves the whole person and the whole community, mutual respect and relationships, and 'service', that people 
perform for their ancestors (Setiloane 1986:15). Berglund (1976) continues Setiloane's explanation by explain the relationship as ukuthetha indlozi, simply meaning the actual communication occurring between a person and Badimo or Amadlozi. The mutual relationship and respect Setiloane refers to becomes a process that continues, even after death.

African religion scholars, such as Mbiti (1986), Thorpe (1975), Setiloane (1986) and Bujo (1992), concede that the concept of Amadlozi or Badimo, within African religious practices, has been wrongly understood right from the outset. Setiloane (1986:17) accepts the term 'living dead' as a working definition of the ancestors, and strongly believes that ancestors are real people ordained as divine. By living dead, Setiloane (1986:21) means that ancestors are not dead, but still live with people in this world as guides for morality and social order. The conscious decision remains to communicate with the living dead through personal contact.

Africans associate the rites and practices of African religion with ancestral beliefs. Richards Norman (2011:105 - 106) argues that the existence of God plays some kind of explanatory role in people's understanding of reality. Religions claim to explain not only how the universe came into existence and continues to operate, but also why human beings understand and respond to these claims.

Murray's work on ritual practices and beliefs recognises the supreme being as Modimo (1980: 123). Murray (1980:24) describes the supreme being as closely associated with natural phenomena and representing the essence of mystery, which evokes a sense of awe (Murray 1980:123). Concurring with Setiloane, Murray concludes that Modimo represents the ultimate source of the human being's well-being. However, God is directly involved in the affairs of the living through Badimo, the ancestors. The most common manifestation of the Badimo is communication by way of dreams.

\section{Sacred Space or Landscape}

The second theoretical framework of this study is based on landscape. We argue that the sacred sites under investigation are integrated into, and are part and parcel of the cultural and religious landscapes of user communities and individuals that are attached to the memories of the living dead. Hirsch (1995:1) refers to the attaching of meaning to landscape as sacred space, as meanings local people ascribe to the cultural and physical surroundings or 
spaces and objects in their living environment. It follows that indigenous people also define landscape in different ways, as it pertains to different, specific environments (Hirst 1995:3).

The concept of landscape is frequently used by anthropologists to casually describe settings pertinent to ethnography (Low \& Lawrence-Zúñiga, 2003:16). Many anthropologists have attempted to problematise the definition of landscape. In this regard, Hirsch (1995:2) observes that all these senses and meanings of landscape, also involve forms of tension between idealised or imagined and real settings, which he calls backgrounds against the foreground of everyday, real, ordinary life. Using this framework, Hirsch explores comparable foreground - background elements of landscape in relation to religion and culture, in different settings, in order highlight the specificities of the relationships between people and their specific environments or sacred spaces and their objects.

\section{Social Identity Theory}

In the view of H. Brown, in 'Themes in Experimental Research on Groups from the 1930s - 1970s' (1996), social identity theory is,

an active research area which may continue to produce much interesting and empirical work, that attempt to resolve the distinction between social theory and personal theory.

He holds that we need to study social identity in an inclusive theoretical framework. We strongly agree with Brown. We need to note that there are many simplistic understandings of indigenous knowledge systems, including African Religion, in so far as they do not acknowledge individual identity as part and parcel of social identity, and vice versa. The two cannot be kept separate from each other, and have to be thought together.

By linking personal identity and social identities, Brown (1996:41) argues that one's experience of social identity affects personality and character and one's identity as a unique individual. This article offers insight into a sample of a complex range of factors that influence the way people see themselves, the way one is seen by others, and the pressure exerted on individuals to adjust to some priority of a social agenda. For instance, following Taylor and Spencer (2004), Spencer (2014:30) argues that identity 
is intensely political, in so far as people are constantly engaged in efforts to escape, fix or perpetuate images and meanings of self and others.

Even so, generically, we may ask, what constitutes or what forms a sense of self when dealing with the identity of people? Is a sense of self made up of the language people speak, the people they live with, the food they eat, the places they go to, the people they associate with? In this regard, in the interests of empirical social identity research, the 'social identity wheel' of Russell (n.d.) is helpful.

\section{SOCIAL IDENTITY WHEEL}

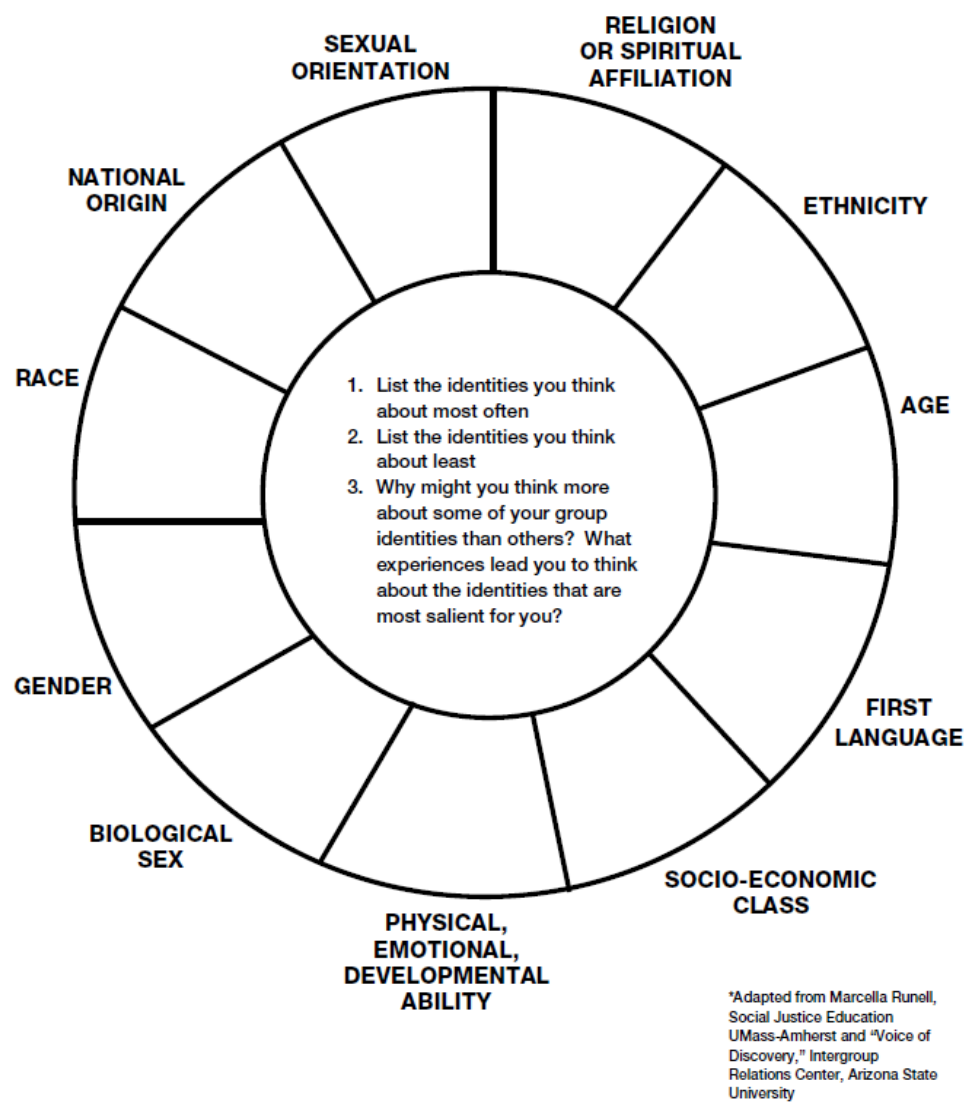


The social identity wheel is helpful, because it provides an example of the kinds of issues that play a role in the shaping and forming of social identities. It could be reconfigured, and more could be added. One could obviously also develop it, indicating how and to what degree, the different aspects articulate with one another, determine one another, and also how individuals, or social formations use them to generate and foster their own distinctive social identities, especially in empirical research. As such, the research could be pursued along these lines of questioning. This, however, is not the main objective of this article.

Furthermore, it should be borne in mind that identity is not found in a vacuum: it is found in communities, societies, nations, and countries, in which all these aspects, amongst others, play a role, in the interests of social identity construction. It is an undisputed fact that various communities have different sets of values, customs, traditions and other factors, that may be used to identify them.

We conclude that people adhere to a religion because it shares the framework of understanding and devotion inherited from the society in which people have been born and raised. The emphasis on religious beliefs suggests that what Kotowski (2011:121) terms social identity construction, that is, to be an African, in our context, is to belong to a particular nation or ethnic group, whose identity is specified by particular aspects of social identity including habits of memory and ritual and of understanding and hope.

Further to the above, Machaba (2004), in his thesis, Naming, Identity and the African Renaissance in a South African Context, explains that an individual may have various social identities, depending on one's personal upbringing and history, which also impacts on where one finds oneself at a particular given time. A person may have more than one sense of self, because one may identify with various people who, in turn, one socialised with at different times of one's life, an in different landscapes, and also with regard to one's exposure to different religions.

This suggests that no one person has only one identity in the eyes of the society in which they live. Even in displacement, the memory of a collective identity may crystallise around a notion of place. In the case of this study, the focus is on how locality as experienced, as a particular space, including the memory of its effects in the past. Each community or individual is part of the chains of attachment to spaces and places, and eventually creates its own social landscape, with related social identities. 


\section{Research Design and Methodology}

This research is positioned within the field of African traditional religion and heritage sites, particularly the sacred cave sites of the eastern Free State. The qualitative method was used to investigate protest and identity with regard to the sacred spaces of the spiritual and cultural landscape of the sacred sites here addressed.

Aspects of this article come from 12 months of fieldwork undertaken by the researcher at three selected sacred cave sites, which are located in a remote area along the Caledon River of the eastern Free State. Research participants informing the research were mainly landowners, government department officials, traditional healers and diviners, and religious groups, individuals, and people experienced in traditional healing and divination within various contexts and capacities.

Part of the research design involved making judgments about the number of participants who were required for this research. Relevant research participants were acquired by means of a purposive sampling survey. Purposive sampling means, according to Gray et al (2007:52), that the researcher deliberately selects the subjects against one or more traits, to give what is believed to be a representative sample. Using this approach, this article succeeded in achieving a true cross-section of the population attached to the sacred sites.

The researcher had undertaken a preliminary study about the population and is confident that all views from all relevant sections of the population were accessed.

Questionnaires, in-depth interviews, and field observations were used for data collection. An open-ended, semi-structured questionnaire and face-toface interviews were designed for this study as an example of interpretative phenomenological analysis. These tools were applied to the research participants and cave dwellers available at the caves. This approach allowed the researcher and participants to engage in a dialogue, eliciting detailed responses and causing initial questions to be modified in the light of the participants' responses. The researcher was successful in probing for interesting and important matters that arose.

The research design applied was the interpretative phenomenological analysis and formed part of qualitative inquiry/ research. This particular research design is informed by interpretative studies through personal interpre- 


\section{Dalifa H.D. Ngobese \& Mogomme Masoga}

tation of the sacred sites' lived experiences and meanings attached to them by indigenous people and cave dwellers. This was used in conjunction with an ethnographic approach, which was used to uncover and explicate the ways in which cave dwellers in the caves and pilgrims to the caves, come to understand, account for, take action, and manage their situations and the challenges and difficulties they encounter in accessing the sacred spaces. Interpretative phenomenological analysis also acknowledges a debt to symbolic interactionism (Denzin 1995), with its concern for the way in which meanings are constructed by individuals within both socially shared and personal understandings of the world ${ }^{2}$.

In utilising this design, the researcher attempts to draw close to the participants' personal worlds, to take, in Conrad's (1987) words, an 'insider's perspective'. These are then interpreted in terms of the conceptual framework, and data and date interpretations provided by existing research. However, one cannot do this directly or completely.

The processes of uncovering and explicating knowledge are typically based on successive observations and interviews, of which a few are referenced in this article. The data was thematised and is briefly discussed below.

\section{Discussion and Data Interpretation}

Caves, as the dwelling sites of Africans, traditional healers, and African churches, represent tranquillity as an important function of African commu-

${ }^{2}$ Interpretative Phenomenological Analysis is described by Smith (2011: 4) as a qualitative research methodology used to understand participants' subjective realities through personal interpretations of their lived experiences and the meanings they attach to these experiences.

We argue that sacred spaces are, indeed, encoded within the African traditional religion and form part of the embodiment of the community's indigenous belief system. Sacred spaces are also used for the engagement of a generic view of ancestral belief; and contributes to the general scientific debate. There is a central belief that sacred cave sites provide the space for ancestral worship and its calling. The connection between sacredness of the space and landscape, African tradition, and adjunct community beliefs is expressed by the practitioners and participants at Mantsopa, Mautse and Motouleng. 
nities. Caves are spaces that offer both protection and shelter because, through their seclusion, they are associated with spiritual dispositions, birth, rituals of life and healing, and regeneration. To Africans, cave sites have the power to preserve and codify, but also revitalise life, as it articulates with indigenous knowledge.

The caves of the eastern Free State represent one of the best codifycations of African indigenous religion and spirituality, in terms of space and landscape. The increasing popularity of pilgrimages to the cave sites provides an ideal geographical context in which peculiar aspects of African religion may be witnessed because of its importance and the histories attached to the caves.

The article does not discuss African religion or spirituality in detail, but selects the most distinctive and observable aspects found at, and understandings of, the caves.

\section{Invocation Rituals}

One of the most important shared practice at all the sites, are the invocation ritual activities. Local or pilgrim user communities always introduce themselves to the ancestors at the entrance to the site. This is a sign of humility, as they are, in a way, asking for permission to enter the sacred sites - the dwelling place of ancestors. Symbolically, to ask for permission to enter the site, represents a sign of respect. The announcement of one's presence and entering into the site indicates respect as well as the dialogical interaction with the ancestors. On entering these sacred sites, one proclaims one's presence to the ancestors (Mensele 2011:30). Respect for the site is tantamount to respect for the ancestors, whom adherents believe to be dwellers and owners of these sacred sites.

\section{Communication with Nkgono Mantsopa}

About the Mantsopa cave site, Bishop Kokota (2016) points out that human life does not terminate at the death of the individual, but continues beyond death. This relates to the importance of ancestors, and how they are associated with certain spaces. He describes how cave dwellers perceive ancestral beliefs:

Batho ba tlang mona ba rometswe ke Badimo ba bona, e kaba Baapostola, dingaka kapa baeti ba lehaha le batho ba kulang. Batho 
ba tlang mona ba tswa dibakeng tse fapaneng mona Afrika borwa le Lesotho. Ho bona lehaha la Mantsopa ke sebaka se halalelang. Ba dumela hore ba bua sefahleho le sefahleho le Nkgono Mantsopa ha ba le mona lehaheng.

People coming here are sent by their ancestors be it apostles, traditional healers and cave dwellers and sick peoples. They are coming from places around South Africa and Lesotho. To them, Mantsopa cave is believed by everyone who come here, to be a holy place, and they attest that they are communicating personally with Nkgono Mantsopa when they are inside the cave.

The 'problem' of the ancestors is at the centre of the age-old controversy about African religion in general. Kuckertz (1985:79) implies that the theme of the 'ancestors' is closely woven into the whole fabric of a then emerging African theology. He quotes Rev. C.G. Baeta's article, entitled The Challenge of African Culture to the Church and the Message of the Church to the African Culture, in which he declares that an African 'lives with the dead' (1955: 60). Kuckertz explains the above notion that the dead are not dead with no impacts in life. Rather, they are a spiritual force that makes life possible (1985: 79).

\section{Becoming a Healer or Sangoma}

The caves are all associated with the calling, and initiation of healers. Masoga (2001:46) says that no-one decides to become a healer. Instead, of someone receives the calling to become a healer, they cannot get away from the calling. One is 'forced' into the role. So, a calling indicates that it is the decision of the ancestors, guided by the ugogo (the departed member of the family), or the ancestral spirit.

Like Berglund, Masoga (2001:46) refers to calling as an actual entry into divination and its intricacies. This is the stage at which the ancestors reveal themselves to an individual or ithwasa (a trainee) through dreams, visions or excessive pain, which is a sign of the presence of ancestors. All the diviners found at the cave sites agreed that nobody can become a diviner by personal choice. Makhosi Mnguni (2003) concurred with them, by saying:

Sangomas had endured a definite way of calling to the institution of bungoma (in a possession stage with ancestral spirits) by the ancestors. 
Excessive headache, drowsiness, terrified dreams, body pain are an exceptionally signs or symbols through the ancestors (amadlozi) call their servants.

All the caves have been and are being used as sites of healing practices including the initiation of diviners and healers. The above definitely applies to the sacred cave sites of the eastern Free State.

Various rituals are performed and described by Mensele, including initiation rituals for the functions of a traditional healer (ho kena lefehlong), or as the first stage or step on the road to becoming a fully-fledged Sesotho traditional healer or doctor (ngaka ya Sesotho). Mensele (2011:128) informs about a number of informants who had undergone formal traditional healer training ritual (ho thwasa/ ho fehlelwa). Masoga (2001:46) also outlines a number of steps and stages in the sangoma training, that must be followed before one qualifies as a sangoma. A central tenet, is that towards the completion of training, it is believed that a diviner cease to think individually, and then starts to listen to what is said by the ancestors (cf. Masoga 2001: 186).

\section{Dreams and Sangoma Training}

In one interview, Mme Masechaba Molefe (2016) emphasised that dreams and songoma training intertwine within ancestral contexts. During her training, there was no prior knowledge of what was expected from her and her fellow trainees, nor of the modus operandi during their training. Dreams are the only means of communication between the trainee and a trainer (ancestor). Most of the sangomas found at these sites, concur that,

Re laelwa ke badimo ditorong (We are instructed by our ancestors in dreams) (Interviewed, 15 July 2016).

It is claimed ancestors are active throughout the training process. It is important for the trainee to frequently invoke the ancestors by means of praying, dancing, and ukuphahla (daily lineage invocation of, or communication with the ancestors) at various features spots in the cave. Berglund (1976:151) points out that diviners who react positively to messages from ancestors cease their training instantly. 
Throughout the training, ithwasa receive a multiplicity of skills inside the cave, be it initiation into the use of herbs for healing, diagnosing of diseases, different forms of interpretation related to divination practices, and healing remedies. The process is undertaken to unveil their ancestral spirits and to remove inner sickness caused by ancestors.

Some of the tactics, such as reinforcing alertness while training is to be performed daily, including ukuhlambuula (cleansing) through amabulawo (emetics) and ukuphalazi (vomiting).

\section{Slaughtering and Sangoma Training}

The researcher observed during the fieldwork undertaken, the killing of animals at Mautse and Motouleng caves. This is what Ray (1976: 84) terms a mediation vehicle between the profane and imperfect world of humanity, and the sacred and ideal world of the ancestors. Usually, before the killing occurs, speeches are made about the particular purpose and circumstances of the sacrifice. Then, the sacrifice is concluded by purifying the patient and sharing the meat, which is viewed as genuine reconciliation and corporate unity.

Details and accounts given by sangomas emphasise that ukubika (introducing), ukuphehla (invoking), and ukubonga (thanksgiving), are reasons for slaughter. Slaughter is necessary so that there can be no misunderstanding between ancestors and sangomas. Sometimes, the family will hide (ukufihla) the animals, and allow the ithwasa to do ukubhula (prophesies). Progressing from the inspection, the ithwasa could be wholeheartedly welcomed and accepted by the family and all the ancestors.

We found that amathwasa have no accurate date for their coming out: the ancestors reveal this to them at a later stage. Berglund adds that training ceases when healing has been completed and divination knowledge assimilated (1976:68), which implies that all the required training activities have been performed. The epistemological concept of dreaming takes its course, and sangomas know when and how are they are expected to come out from the cave.

The success of the sangoma is seen from their intellectual capability, knowledge, intuition, and capacity to translate supernatural messages. These experiences indicate the completion of the course of becoming a sangoma. The ithwasa's ability to approach the ancestors in a convincing manner, ukuthetha idlozi (to scold), diagnose disease, or to find a lost item, are publicly evaluated by relatives, adherents, and the ancestors. 


\section{Rituals}

Rituals that are performed at the cave sites are seasonal, and performed in conunction with particular life circumstances or events in the life of a social group, or a specific celebration in a specific month of the year, or for training as sangoma, or for healing rituals proper. Among the numerous rituals that are performed, there are divinatory rituals, healing rituals, initiation rituals and other rituals that provide senses of belonging, unity, and continuity amongst those who perform or attend the events. Mbiti (1990:131) points out that people find a degree of identity through their participation in these common events, via their own lived participation in, and lived experience of the rituals.

Furthermore, the concept of rituals pervades African wisdom and knowledge. In terms of experiential narrative discourse, rituals have two dimensions: what is 'said' and what is 'done'. A ritual does or attempts to do a variety of practical things. Ritual is a way of communicating with divine being for the purpose of changing the human situation. This is done through things said, but also done - i.e. experiences in the participation in a ritual through speech and/ or through certain acts that the ritual prescribes (Ray 1976: 78).

Concurring with Ray, Berglund (1976) refers to a ritual as a celebration that aims to achieve communion with amadlozi. In ritual, people are able to return to the origins of their world, to experience the creation of order out of chaos, and to find themselves renewed, individually, but also as social groups (cf. also Cox 1992:81).

Cox (1992: 82) adds that some rituals occur in sacred spaces different from other spaces. These rituals may be defined as seasonal, occurring at various times of the year and often relating to a person's needs and ancestral callings. Rituals occur in different areas with prescribed regulations aimed at fulfilling certain criteria, such as training by an experienced sangoma, as directed by ancestors.

Mensele's unpublished thesis, titled A Study of Rituals Performed at the Two Sacred Sites in the eastern Free State (2011), describes how the invocation ritual is performed as part of a rite of passage. This thesis concludes that the core aspects of Basotho tradition and culture is respect of the 'living', as well as of those who have departed (ancestors). It is not surprising, therefore, that this kind of respect is displayed by local user communities visiting the sacred sites at Mautse and Motouleng caves. 


\section{Education}

Cave dwellers define a sacred cave as 'Ke yunivesiti ya rona' (it's our university). They equate cave sites with institutions of education. They refer to the knowledge and power of the territory, which they say, inspire and sustain their lives, knowledge, via ancestor veneration. Their rites give them strength and energy to live, and, to a sangoma, the power to heal any disease. These believes and practices constitute systems of knowledge, that form part of the 'defences' of the human spiritual legacy of most African clans or groups, against outside interference and encroachment on their ways of life.

\section{Geographical Space}

In his chapter, 'The Sharing and Dividing of Geographical Space', Smith (1990:3) indicates that humanity establishes identities that include aspects of geographical space. Humans create senses of place with the deepest emotional ties and feelings. This includes perceptions of territory as a source of human identity, for expressing what may have been the harrowing historical experience of surviving the struggle with nature or hostile competitors for territory.

The formal social exclusion of individuals or distinctive groups of people was a long-established practice in South Africa. In this regard, and because of this reality in South Africa's history, Smith (1990:8) explains that geographical space is deeply implicated in social exclusion. He implies that physical propinquity and the forceful separation of people from their indigenous space(s) form important parts of their identity, and that their quest to be re-united with these spaces, equally form an important part of their social identities.

\section{Recommendations}

People are very dissatisfied with farm owners who use the boundaries outside the sacred cave to contest what cave dwellers identify as non-farming activities. In some cases, cave dwellers are prevented from practicing their rituals in and at the caves. This continues the separation from the sacred paces from which the cave dwellers' ancestors were separated. This leads to contestations and protests by cave dwellers pilgrims, and diviners and traditional healers, who perceive the sacred sites as religious spaces. Through 
the protests they also contest the fact that the sites have been earmarked as sites for commercialised tourism, with the related facilities, and where they are forced to pay to enter. It includes individual tourist operators and government department officials who wish to increase their business by extending their cultural tourism initiatives at cave sites.

David Kgoabane (Interviewed, 17 July 2017) confirms that there has been ongoing conflict and contestation amongst the cave dwellers, between officials and visitors, cave dwellers and pilgrims and farm owners about the use of the sacred space at Mautse sacred site. Farm owners see the visits and ritual practices at the caves, as invasive to their farming activities, seeing that they have involved livestock rustling, and unrelated forms of trespassing.

In the light of these challenges, and the research conducted, we suggest that the farm owners come to forms of agreement with indigenous practitioners who want to visit the sites for their different religious practices. Many undertake a pilgrimage and arduous journey to the sacred space just to be then turned away. In this context, farm owners and government should strike a balance against prohibiting religious groups to visit the sites, and and freedom of speech or association, as enunciated in Article 20 of the International Covenant on Civil and Political Rights (ICCPR) of 1966 (cf. Lerner 2000:39). There is a solution for conflict and contestation at sacred sites, which depends on the constitutional systems of respective countries. Provincial and national legislations in South Africa have provided a guideline on how sacred sites should be managed and preserved. For example, South Africa's National Heritage Resources Act, 25 of 1999 (Republic of South Africa, 1999), instigates the promotion and protection of sacred sites, whether graves, landscapes, mountains, rivers or pools, that are considered sacred and used by communities for cultural practices.

Lerner (2000:40) confirms that current trends in connecting with religion rights, seem to indicate a growing understanding of the need to protect substantive social values against abuses of freedom of speech and association. Surely, there is a need to ensure the protection of religious, ethnic and cultural groups, irrespective of the nature of the religion, or adherents' colour or beliefs, not least with regard to these sacred caves. This should also be seen as reconnecting indigenous people to their heritage(s), the decolonisation of indigenous knowledge systems, and not the continued separation of people from their meaning giving contexts (cf. Simpson 2001:139).

We argue, furthermore, that the notion of Ubuntu (humanity towards 
others, in terms of one's own humanity) appears to have been eroded, to the extent that it is currently seems unable to play a meaningful role in nation building. As a society that has undergone continuous change, South Africa is in a liminal space characterised by both threat and possibility. Eliastam (2015:1) explains that eroding positive social values poses a threat, namely, fragmenting society until it tears apart. On the contrary, ubuntu practices related to the reconnection of people(s) with their erstwhile ancestral lands, will foster a renewed African identity (Cloke \& Little1997:279).

The ongoing debate, disputes and contestation between farm owners and cave dwellers and pilgrims led to the closure of Mautse cave site, and failure of government and the authorities to intervene in the protest and contestation has been a crucial shortcoming of protecting indigenous knowledge with regard to belief, healing, and practices.

\section{Conclusion}

What the cave dwellers and pilgrims practice and perceive with regard to sacred sites remains a taboo to 'outsiders'. Yet, despite this hiatus, it is important to develop systems through which people who have been alienated from their ancestral lands, can re-connect with them, via their indigenous knowledge and ritual practices. The article has provided a few geo-historical perspectives on the sacred cave sites, and with regard to a conceptual framework related to religion, landscape (sacred space) and social identity, pointed to some meaningful steps that may be taken to reconnect the cave dwellers, diviners, healers and pilgrims, to their ancestral lands.

The interviewees sites agreed that the sacred caves play meaningful roles in their lives. By thematising some of the data, the article has sought to unpack some of these themes, as they relate to the sites. These sites are places imbued with sacred power, at which ancestors (ke sebaka sa Badimo) are encountered and from which indigenous knowledge practitioners draw their meaning, healing and vitality.

Tensions between farm owners, tourist professionals and cave dwellers and pilgrims need to be considered constructively, and requisite management plans drafted for the sites. On the one hand, practitioners should get access to the sites. On the other hand, land owners need to be educated about the significance of the sites for adherents to the indigenous knowledge and related rituals and practices. 


\section{References}

Baeta, C.G. 1962. Prophetism in Ghana. USA: Princeton.

Berglund, A. 1976. Zulu Thought-Patterns and Symbolism. Johannesburg: David Phillip Publishers.

Becker, P. 1969. Hill of Destiny: The Life and Times of Moshesh, Founder of the Basotho. London: Longman group LTD.

Bujo, B. 1992. African Theology in its Social Context. New York: Orbis Books. Brown, H. 1996. Themes in Experimental Research on Groups from the 1930s - 1970s. In Wetherell, M. (ed.): Identities, Groups and Social Issues. London: Sage.

Brown, D. 2009. Religion and Spirituality in South Africa: New Perspectives. Scottville: University of KwaZulu- Natal Press

Carmichael, D.L. et al. 1994. Sacred Sites and Sacred Places. London: Routledge.

Cloke, P. \& J. Little 1997. Contested Countryside Cultures. New York: Routledge.

Coleman, S. 2002. Do you Believe in Pilgrimage? Communitas, Contestation and Beyond. Anthropological Theory 2: 355 - 368.

https://doi.org/10.1177/1463499602002003805

Conrad, P. 1987. The Experience of Illness: Recent and New Directions. Research in Sociology of Health Care 6: 1- 13.

Coplan, D.B. 2003. Land from Ancestors: Popular Religious Pilgrimage along the South Africa - Lesotho Border. Journal of Southern Africa Studies 29, 4. https://doi.org/10.1080/0305707032000135923

Cox, J.L. 1992. Expressing the Sacred: An Introduction to Phenomenology of Religion. NCR City: Haran.

Davenport, T.R. 1978. South Africa: A Modern History. $2^{\text {nd }}$ Edition. Johannesburg: MacMillan Publishers.

Denzin, N. 1995. Symbolic Interactionism. In: Smith, J.A., R. Harre \& L. van Langenhoven (eds.): Rethinking Psychology. London: Sage.

Eliade, M. 1959. The Sacred and Profane: The Nature of Religion. USA: Harcourt.

Eliade, M. 1963. Myth and Reality. USA: Harper and Row Publishers. Gray, P.S. 2007. The Research Imagination: An Introduction to Quantitative and Qualitative Methods. USA: Cambridge University Press.

Hirsch, E. 1995. The Anthropology of Landscape: Perspectives on Places and 
Dalifa H.D. Ngobese \& Mogomme Masoga

Space. Oxford: Clarendon Press.

Jordan, B. 2000. Unholy Row over Sacred Cave. The Sunday Times 09 July 2000: 7 - 8.

Kotowski, J.M. 2011. The Discursive Construction of National Identities through Narratives of Immigration in German and American Social Studies Textbooks. USA: Santa Cruz.

Kuckertz, H. 1985. Ancestor Religion in African Theology: A Review. In Ancestor Religion in Southern Africa. Proceedings of a Seminar on Ancestor Belief. USA: Lumko Missiological Institute.

Lebel, D. \& C. Hubert 1995. Geologie de la rếgion de Saint-Raphael (Chaudière-Appalaches). Quebec: Ministerè de I'Énergie te des Ressources du Quebec.

Lerner, N. 2000. Religion, Beliefs, and International Human Rights. New York: Orbis Books.

Lye, W.F. \& C. Murray 1980. Transformation on the Highveld: The Tswana and Southern Sotho. Cape Town: David Phillip.

Low, S.M. \& D. Lawrence-Zu'niga 2003. Locating Culture. Oxford: Blackwell Publishing Ltd.

Machaba, M.B. 2004. Naming, Identity and the African Renaissance in a South African Context. Unpublished $\mathrm{PhD}$ thesis. University of Natal.

Masoga, M.A. 2001. Dimensions of Oracle Speech in the Near Eastern, Mediterranean and African Context: A Contribution towards African Orality. University of the Free State, Unpublished $\mathrm{PhD}$ thesis. Bloemfontein.

Mbiti, J.S. 1969. African Religion and Philosophy. Nairobi: East Africa Educational Publishers.

Mbiti, J.S. 1989. African Religion and Philosophy. $2^{\text {nd }}$ Edition. Oxford: Heinemann Educational Publishers.

Mbiti, J.S. 1990. African Religion and Philosophy. $3^{\text {rd }}$ Edition. Oxford: Heinemann Educational Publishers.

Mensele, M.S. 2011. A Study of Rituals Performed at Two Sacred Sites in the Eastern Free State. Unpublished MA thesis. University of Free State. Bloemfontein.

Motloung, R. 2003. The Prospect of Tourism Development of the Eastern Free State. Unpublished Honours Dissertation. University of the North, Qwaqwa Campus.

Murray, J.B. 1980. Spirituality in Art. USA: Padgelek. 
Pungetti, G. et al. 2012. Sacred Species and Sites: Advances in Biocultural

Conservation. United Kingdom: Cambridge University Press.

https://doi.org/10.1017/CBO9781139030717

Pungetti, G. et al. 2012. Ecological and Spiritual Values of Landscape: A

Reciprocal Heritage and Custody. In Pungetti, G., G. Oviedo \& D. Hooke (eds.): Sacred Species and Sites: Advances in Biocultural Conservation. United Kingdom: CUP.

Ray, B.C.1976. African Religion: Symbols, Ritual and Community. New Jersey: Prentice- Hall Inc.

Runell, M. n.d. Social Justice Education. Amherst: University of Massachusetts, Intergroup Relations Centre.

Setiloane, G.M.1986. African Theology: An Introduction. Johannesburg: Skotaville.

Simpson, L. 2001. Aboriginal People's Knowledge: Decolonizing our Process. The Canadian Journal of Native Studies XXI,1: 137 - 148.

Smith, D.M. 1990. Human Territoriality. In Chisholm, N. \& D. Smith (eds):

Shared Space and Divided Space: Essays on Conflict and Territorial Organization. London: Unwin Hyman.

Smith, J.A., P. Flowers \& M. Larkin (eds.). 2011. Interpretative Phenomenological Analysis: Theory, Method and Research. USA: SAGE.

South African National Heritage Act, No 25, 1999. National Department of Arts and Culture.

Spencer, N. 2014. Kom Firin II: The Urban Fabric and Landscape. London:

British Museum Press. (The British Museum Research Publications Number 192.)

Taylor, J.V. 1963. The Primal Vision: Christian Presence amid African Religion. USA: SCM Press.

Taylor, G. \& S. Spencer 2004. Social Identities: Multidisciplinary Approaches.

London: Routledge.

https://doi.org/10.4324/9780203338674

Tilley C. 1994. A Phenomenology of Landscape: Places, Paths and Monuments. Oxford: Berg Publishers.

\section{Personal Communication}

Kokota, L. 2017. Interviewed at Motouleng Cave Site, in Clarens, 18 July 2017. 
Dalifa H.D. Ngobese \& Mogomme Masoga

Molefe, M. 2016. Interviewed at Motouleng Cave Site, Clarens, 26 November 2016.

Mnguni, T. 2017. Interviewed at Osizweni Township, Newcastle, 05 August 2017.

Nkgoabane, D. 2017. Interviewed at Mantsopa Cave Site, Modderpoort, 19 July 2017.

Ngema, S. 2017. Interviewed at Dihlabeng Local Municipality, Bethlehem, 18 July 2017.

Dalifa H.D. Ngobese History Faculty of Arts University of Zululand

Kwadlangezwa

NgobeseD@unizulu.ac.za

Mogomme A. Masoga Dean of the Faculty of Arts University of Zululand

Kwadlangezwa MasogaM@unizulu.ac.za 